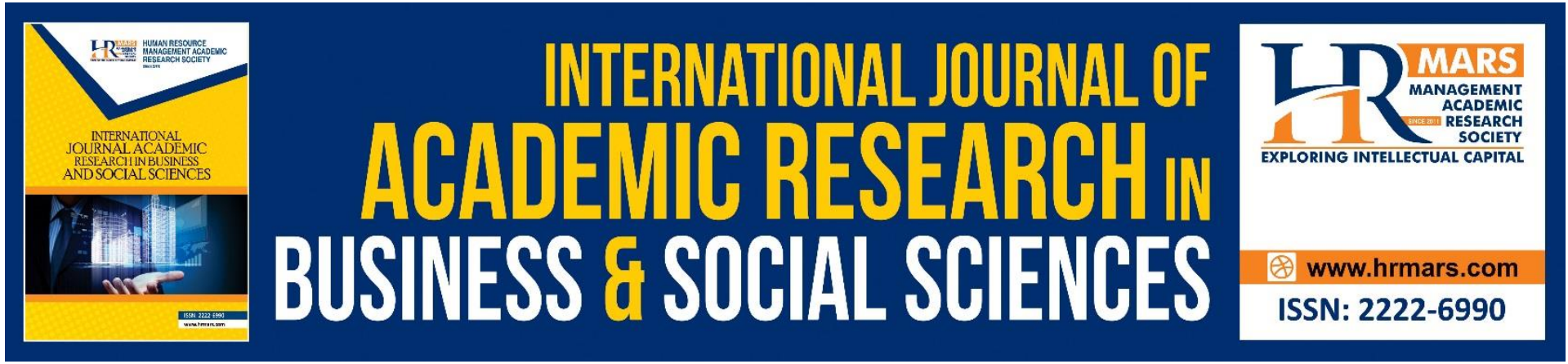

\title{
Handicraft Industry Entrepreneurial Ecosystem (HIEE): An Empirical Evidence of Malaysian Handicraft Micro and Small Industry Entrepreneurs
}

Norashikin Hussein, Muhamad Khalil Omar, Ehsan Fansuree Mohd Surin

To Link this Article: http://dx.doi.org/10.6007/IJARBSS/v11-i6/10337 DOI:10.6007/IJARBSS/v11-i6/10337

Received: 11 April 2021, Revised: 15 May 2021, Accepted: 04 June 2021

Published Online: 20 June 2021

In-Text Citation: (Hussein et al., 2021)

To Cite this Article: Hussein, N., Omar, M. K., \& Surin, E. F. M. (2021). Handicraft Industry Entrepreneurial Ecosystem (HIEE): An Empirical Evidence of Malaysian Handicraft Micro and Small Industry Entrepreneurs. International Journal of Academic Research in Business and Social Sciences, 11(6), 1267-1278.

Copyright: @ 2021 The Author(s)

Published by Human Resource Management Academic Research Society (www.hrmars.com) This article is published under the Creative Commons Attribution (CC BY 4.0) license. Anyone may reproduce, distribute, translate and create derivative works of this article (for both commercial and non-commercial purposes), subject to full attribution to the original publication and authors. The full terms of this license may be seen at: http://creativecommons.org/licences/by/4.0/legalcode

Vol. 11, No. 6, 2021, Pg. 1267 - 1278

Full Terms \& Conditions of access and use can be found at http://hrmars.com/index.php/pages/detail/publication-ethics 


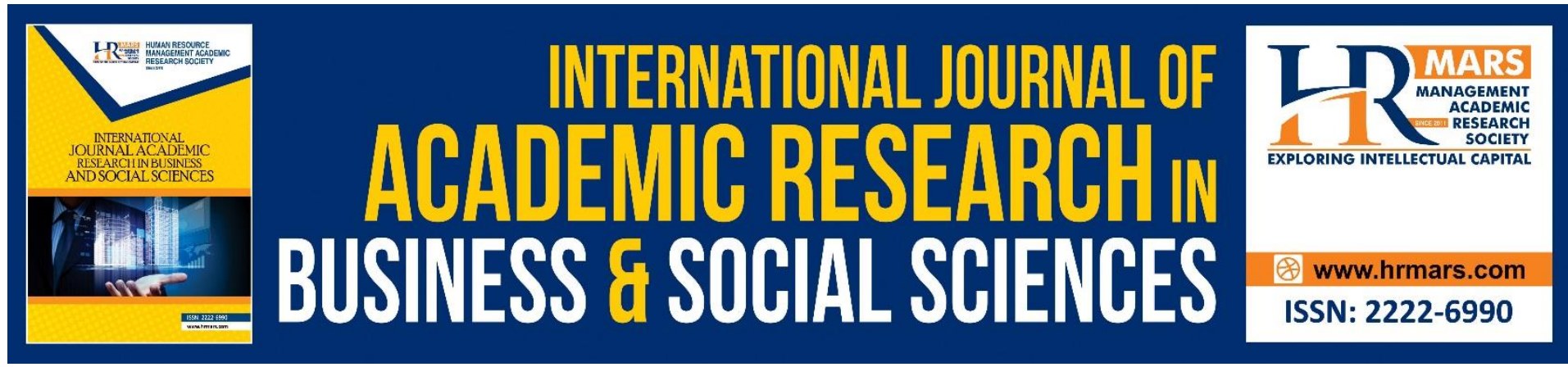

\title{
Handicraft Industry Entrepreneurial Ecosystem (HIEE): An Empirical Evidence of Malaysian Handicraft Micro and Small Industry Entrepreneurs
}

\author{
Norashikin Hussein, Muhamad Khalil Omar, Ehsan Fansuree \\ Mohd Surin \\ Faculty of Business and Management, Universiti Teknologi MARA Cawangan Selangor, \\ Puncak Alam Campus, 42300 Bandar Puncak Alam, Selangor \\ Email: shikin6320@uitm.edu.my, ${ }^{2}$ khalil.omar@uitm.edu.my, ${ }^{3}$ efansuree@uitm.edu.my
}

\begin{abstract}
Handicraft industries continue to play an important role in the economies of all Asian countries including Malaysia. They not only constitute small business activities in themselves but are also often the only available means to provide additional employment and raise the level of living for rural populations. Despite the government's several institutional and policy support for enhancing the capacity of micro and small-scale enterprises, the results have fallen short of expectations. In view of the growing world market for products of traditional Asian handicraft industries, having a relevant entrepreneurial ecosystem model specific to handicraft micro and small industries in Malaysia is imperative. Thus, this study attempts to: (1) identify the components of entrepreneurial ecosystem of handicraft micro and small industries in Malaysia; (2) determine the relationship between components of entrepreneurial ecosystem

and business performance. The SEM-PLS approach has been employed as a statistical method to analyze the research model. Data were collected from 50 handicraft micro and small entrepreneurs using personally administered questionnaire surveys. The findings indicate that only talent was found to have a significant relationship with business performance. This study is significant to the investors, the ministry, the government, academics and even business owners in providing a comprehensive model in understanding the handicraft industry entrepreneurial processes through which the ecosystems emerge, change, and influence the activities of the entrepreneurs.
\end{abstract}

Keywords: Entrepreneurial Ecosystem, Handicraft Industry, Micro and Small Industry

\section{Introduction}

Entrepreneurship or new firm formation is a fundamental process of economic geography (Stam, 2007). In order for a firm to be successful, a conducive environment in which they can innovate and prosper their business is vital (Maroufkhani, Wagner \& Wan Khairuzzaman (2018). In other words, the success of entrepreneurship greatly depends on its ecosystem. 
Bibliometric evidence shows that usage of the term entrepreneurial ecosystem has overtaken other concepts, such as environments for entrepreneurship, which also highlight the mechanisms, institutions, networks, and cultures that support entrepreneurs (Malecki, 2018). In reaction to the decline in new firms in recent decades (Decker et al., 2016), there is a strong need to clearly understand the entrepreneurial ecosystem for the various industries to enable effective development of right policy and initiatives by all stakeholders. This is due to the fact that the entrepreneurial ecosystem is a system of interrelated components that impact the speed and ability with which can guide the entrepreneurs to create and scale new ventures in a sustainable way.

Entrepreneurial ecosystem is a dynamic, self-regulating network of many different types of actors that are coordinated in such a way that they enable productive entrepreneurship (Isenberg, 2014; Stam, 2015). Audretsch and Belitski (2017) define systems of entrepreneurship (further ecosystem) as institutional and organizational as well as other systemic factors that interact and influence identification and commercialization of entrepreneurial opportunities. Discussion of entrepreneurial ecosystems has largely focused on the essential ingredients, while largely ignoring the processes for their combination into a sustainable milieu with entrepreneurial vitality.

Despite the importance of the entrepreneurial ecosystem as a critical tool for creating resilient economies based on entrepreneurial innovation, study on the entrepreneurial ecosystem is still underdeveloped and under theorized (Spigel, 2017). Questions such as what consisted an entrepreneurial ecosystem model for example, is still need an answer (Yan \& Guan, 2019).

Previous studies highlight that there is significant overlap in many of the previous approaches in modeling entrepreneurial ecosystems. In fact, there is still no generally accepted taxonomy on entrepreneurial ecosystems specifically in the context of handicraft industry in Malaysia.

\section{Handicraft Industry in Malaysia}

Handicrafts are commonly defined as handmade items made using simple tools and are generally artistic and/or traditional in nature (Yojana and Sansad, 2006). Handicraft industries continue to play an important role in the economies of all Asian countries. They are often the only available means to provide additional employment and raise the level of living for both rural and urban populations in certain parts of Asia. In Malaysia, the handicraft industry is taken care of by Malaysian Handicraft Development Corporation, under the Ministry of Tourism, Arts and Culture Malaysia. Most of the handicraft businesses in Malaysia are categorized under micro and small business industries as defined by SME Corp. Malaysia. Micro and small business industries are defined as businesses that have sales turnover less than RM 3 million and employ less than 30 employees (http://www.smecorp.gov.my/index.php/en/policies/2015-12-21-09- 09-49/sme-definition). In general, handicraft industries in Malaysia contribute key economic revenues for the village population. The incomes derived from the industries contribute the main part of total rural household income (Redzuan \& Aref, 2009). The village people in north-eastern coasts of Malay Peninsula are largely accountable for passing the centuries-old tradition and heritage to the younger generations. The most famous handicraft industry for villages in Malaysia are Batik, Songket, silversmith and Wau (big kite) in Kelantan and Terengganu. In addition, the majority of the micro industry such as handicraft in Malaysia are women. One possible reason for the high involvement of women is related to the characteristics of the industry (e.g. home based, minimum requirement of overhead expenses and infrastructure) that hold advantages for them in starting their businesses (Zainol, Al Mamun, Ahmad, \& Simpong, 2018). Even 
though Malaysia receives more support by relevant agencies in assisting the development of handicraft industries compared to its neighbouring countries such as Thailand and Indonesia, our crafts products have a long way to go with those produce.by these countries (Redzuan \& Aref, 2011).

As the backbone of a country's economy and their significant presence and role to the nation, the handicraft industry in Malaysia needs to be more aggressive to improve their productivity and competitiveness. In order to move up the value chain in this increasingly competitive economic environment, understanding the ecosystem of the handicraft industry in response to the business environment are vital. Thus, this study aims to: 1 ) identify the components of the entrepreneurial ecosystem of handicraft micro and small industries in Malaysia; (2) determine the relationship between components of entrepreneurial ecosystem and business performance.

\section{Literature Review \\ Entrepreneurial Ecosystem}

The notion of an entrepreneurial ecosystem (or ecosystem for entrepreneurship) is still in its infancy stage and has emerged from diverse origins. Table 1 provides evidence of the shift from entrepreneurial environments to entrepreneurial ecosystems in scholarly publishing, based on searches in Web of Science (WoS) and Scopus during October 2017 of the full range of sources (journal articles, book chapters, proceedings, and others) in the two databases. Entrepreneurial environment (or similar phrases) was the most common term used in the literature from the 1970s through 2015. Entrepreneurial ecosystem emerged only in the 2000s but has become dominant since 2016. Alternative concepts, such as systems of entrepreneurship and infrastructure for entrepreneurship, continue to be used but remain less prevalent, as indicated by Alvedalen and Boschma (2017).

Table 1. Number of papers on entrepreneurial context (environment, ecosystem, infrastructure, system) in Scopus and Web of Science, 1970s to 2017

\begin{tabular}{|c|c|c|c|c|c|c|c|c|}
\hline \multirow[t]{2}{*}{ Year } & \multicolumn{2}{|c|}{ Environment } & \multicolumn{2}{|c|}{ Ecosystem } & \multicolumn{2}{|c|}{ Infrastructure } & \multicolumn{2}{|l|}{ System ${ }^{d}$} \\
\hline & Scopus & Wos & Scopus & Wos & Scopus & Wos & Scopus & Wos \\
\hline $1970=$ & 4 & 4 & o & o & o & 0 & 2 & 1 \\
\hline $1980 \mathrm{~s}$ & 11 & 2 & 0 & 0 & 0 & 0 & 1 & 0 \\
\hline $1900-1090$ & 13 & 10 & 0 & o & 2 & 1 & 7 & 7 \\
\hline $2000-2009$ & 99 & 76 & 5 & 2 & 6 & 3 & 17 & 10 \\
\hline $2010-2015$ & 145 & 166 & 71 & 45 & 20 & 6 & 34 & 26 \\
\hline $2016-2017$ & 51 & 50 & 139 & 69 & 4 & 3 & 32 & 18 \\
\hline Tatal & 324 & 305 & 215 & 116 & 32 & 13 & 93 & 62 \\
\hline
\end{tabular}

(Source: Malecki, 2018)

Spigel (2015) provides a useful top-level view, categorising entrepreneurial ecosystem elements into cultural, social and material attributes. Cultural attributes include the disposition of the local area towards entrepreneurialism - for instance whether entrepreneurialism is seen as an esteemed career choice -- and narratives of success - those who have followed the entrepreneurial path and 'made it big'. Social attributes relate to interpersonal and relationship

based elements, such as social networks, investment capital, mentors, human capital and 
'deal makers'. Interestingly, Spigel (2015) calls out not just hard skills as a factor here, but also mindset-related capabilities such as risk tolerance - required to thrive in entrepreneurial settings. Material attributes include universities, support services and facilities, policy and governance and open markets. Based on Spigel's framework, it is proposed that the components be divided into high priority and medium priority attributes as displayed in Table 2. The components of entrepreneurial ecosystem used in this study consisted of market (network and engagement; support services), talent (education and training; regional culture) and finance (physical infrastructure; government regulatory and framework).

Table 2. Proposed attributes of Handicraft Industry Entrepreneurial Ecosystem (HIEE) based on various literature (e.g Isenberg, 2014; Stam, 2015; Spigel, 2017)

\begin{tabular}{|c|c|c|c|}
\hline \multicolumn{2}{|c|}{ High Priority Attributes } & \multicolumn{2}{|c|}{ Medium Priority Attributes } \\
\hline \multirow[t]{2}{*}{ Market } & \multirow[t]{2}{*}{$\begin{array}{l}\text { The availability of, } \\
\text { and ability to } \\
\text { identify, reach and } \\
\text { sell to a market or } \\
\text { market segment }\end{array}$} & $\begin{array}{l}\text { - Network and } \\
\text { Engagement }\end{array}$ & $\begin{array}{l}\text { The richness and vibrancy of networks } \\
\text { and inter-relationships in the } \\
\text { entrepreneurial community and the } \\
\text { opportunity to meet, interact and build } \\
\text { new relationships. This element also } \\
\text { concerns the governance of the } \\
\text { ecosystem itself. }\end{array}$ \\
\hline & & $\begin{array}{l}\text { - Support } \\
\text { Services }\end{array}$ & $\begin{array}{l}\text { The availability of, and ability to access } \\
\text { legal, financial, real estate, consulting } \\
\text { and related services, including } \\
\text { mentoring and role models. }\end{array}$ \\
\hline \multirow[t]{2}{*}{ Talent } & \multirow{2}{*}{$\begin{array}{l}\text { The availability of, } \\
\text { and ability to } \\
\text { attract and retain } \\
\text { highly skilled } \\
\text { people with the } \\
\text { right mindset for } \\
\text { entrepreneurial } \\
\text { activity. }\end{array}$} & $\begin{array}{l}\text { - Education and } \\
\text { Training }\end{array}$ & $\begin{array}{l}\text { The availability of, and ability to access } \\
\text { entrepreneurial and related education } \\
\text { and skills development, technology } \\
\text { transfer processes and the quality of } \\
\text { the labour force pipeline. }\end{array}$ \\
\hline & & $\begin{array}{l}\text { - Regional } \\
\text { Culture }\end{array}$ & $\begin{array}{l}\text { The region's attitude and cultural } \\
\text { inclination towards entrepreneurial } \\
\text { activity; tolerance for risk and failure; } \\
\text { narratives of success that serve to } \\
\text { inspire others }\end{array}$ \\
\hline Finance & $\begin{array}{l}\text { The availability of, } \\
\text { and ability to access } \\
\text { grants, venture } \\
\text { capital, } \\
\text { investment, seed } \\
\text { funding and other } \\
\text { forms of capital }\end{array}$ & $\begin{array}{l}\text { - Physical } \\
\text { Infrastructure }\end{array}$ & $\begin{array}{l}\text { The availability of, and ability to access } \\
\text { real estate, infrastructure such as } \\
\text { internet and transportation to enable } \\
\text { startup and growth. This includes 'third } \\
\text { spaces' - } \\
\text { makerspace, co-working hubs, } \\
\text { technology parks etc. }\end{array}$ \\
\hline
\end{tabular}




\begin{tabular}{|l|l|l|l|}
\hline $\begin{array}{l}\text { needed } \\
\text { initiation } \\
\text { growth. }\end{array}$ & $\begin{array}{r}\text { for } \\
\text { and }\end{array}$ & $\begin{array}{l}\text { Government } \\
\text { and } \\
\text { Regulatory } \\
\text { Framework }\end{array}$ & $\begin{array}{l}\text { The degree to which government } \\
\text { policies, frameworks and incentives } \\
\text { foster or inhibit the initiation and } \\
\text { grown of entrepreneurial activity. }\end{array}$ \\
\hline
\end{tabular}

Previous literature has demonstrated various factors that lead to business performance among small and medium enterprises (SMEs). Rajah and Wan Fauziah (2019) for example examine six components of the entrepreneurial ecosystem on SMEs business performance in Malaysia. The findings indicate that the entrepreneurial ecosystem and all six domains are positively correlated to business performance, and the most significant of the six domains is human capital. In addition, other studies that emphasized the entrepreneurial ecosystem highlighted the importance of various components including market, finance and talent and business performance in the entrepreneurial context (e.g Isenberg, 2014; Stam, 2015; Spigel, 2017). Therefore, it is proposed that :

$H_{1}$ : There is a positive significant relationship between market and business performance $\mathrm{H}_{2}$ : There is a positive significant relationship between talent and business performance $\mathrm{H}_{3}$ : There is There is a positive significant relationship between finance and business performance

\section{Method}

This study utilized a quantitative research design. Data were collected using personally administered questionnaire survey from handicraft entrepreneurs registered under the Malaysian Handicraft Development Corporation, Ministry of Tourism, Arts and Culture Malaysia. Purposive sampling was adopted in this study as it represents particular characteristics that are of interest. Market which is categorized into two dimensions namely network and engagement, and support service was measured using ten items adapted from Saad (2014). To measure talent, two dimensions were used to describe the variable, namely education and training, and regional culture. 10 items adapted from Khadhraoui, Plaisent, Lakhal and Prosper (2016), and Grohmarm and Kauffeld (2013) were used in measuring the variable. Finance was measured using two dimensions namely physical infrastructure, and government and regulatory framework. For this measurement, 10 items were adapted from Byrd (2018) and Saad (2014). In measuring these three main variables (market, talent and finance), participants responded to items based on a seven-point Likert scale ranging between $1=$ Never to 7 = Always. Lastly, to measure business performance, 10 items were adopted from Ngah (2011) and Surin (2014). All these items were measured on a 7 point Likert scale ranging between 1 = Strongly Disagree to 7 = Strongly Agree. Structural Equation Model Partial Least Square (SEM-PLS) was employed as a statistical analysis to allow the researcher to examine the relationship among the constructs. Structural Equation Model Partial Least Square (SEM-PLS) approach has been employed as a statistical method to analyze the research model using the SmartPLS 3.0 software. Following the recommended two-stage analytical procedures by Anderson and Gerbing (1988), where the measurement model was tested first to validate the instrument and followed by the structural model examination to test the relationships that were hypothesized. Bootstrapping technique (2000 resamples) was employed to test the significance levels of path coefficients among constructs (Hair, Hult, Ringle, \& Sarstedt, 2016). 


\section{Results and Discussion \\ Demographics Profile}

A total of 50 handicraft micro and small business owners responded to the study. Majority of the respondents $(n=44)$ are the owners of sole proprietorship of their business. Most of the entrepreneurs are running a family business $(n=33,66 \%)$ and out of these 33 entrepreneurs, 21 respondents (42\%) are the second generation that operate the business. Most of the businesses employ 1 to 5 employees $(n=37)$ followed by 6 to 10 employees $(n=11)$. The handicraft types of industry is categorized to a few groups namely metal based (e.g., copper and metal) ( $n=4,8 \%$ ), textile (e.g., batik and songket) ( $n=19,38 \%)$, forestry based (e.g., rattan and wood based) ( $n=14,28 \%)$, soil based (e.g., seramic) $(n=3,6 \%)$, miscellaneous (e.g., plastic based, beads and other types of products that are not categorized) ( $n=10,20 \%) .62$ percent of the respondents have a monthly gross revenue of RM10k, followed by 24 percent respondents with gross revenue of RM10K - RM19,999.

\section{Measurement Model}

There are two types of validity that will be examined to assess the measurement model, namely convergent validity and discriminant validity. First, convergent validity testifies how well the construct describes its indicators' variance (Hair et al., 2016). The convergent validity of the measurement is usually determined by assessing the loadings, Average Variance Extracted (AVE) and Composite Reliability (CR) (Gholami, Sulaiman, Ramayah, \& Molla, 2013). The suggested loadings values are set at $>0.5$, Average Variance Extracted (AVE) should be $>$ 0.5 and the Composite Reliability should be set at > 0.7 (Hair et al., 2014; Hair, Ringle, \& Sarstedt, 2011; Hair et al., 2016). Figure 1 shows the final assessment of the measurement SEM PLS framework used in the study. Table 3 and 4 shows that the measurement model results exceeded the recommended values, indicating adequate composite and convergent validity. A few items were deleted for better AVE (Hair et al., 2014; Hair et al., 2011; Hair et al., 2016). 


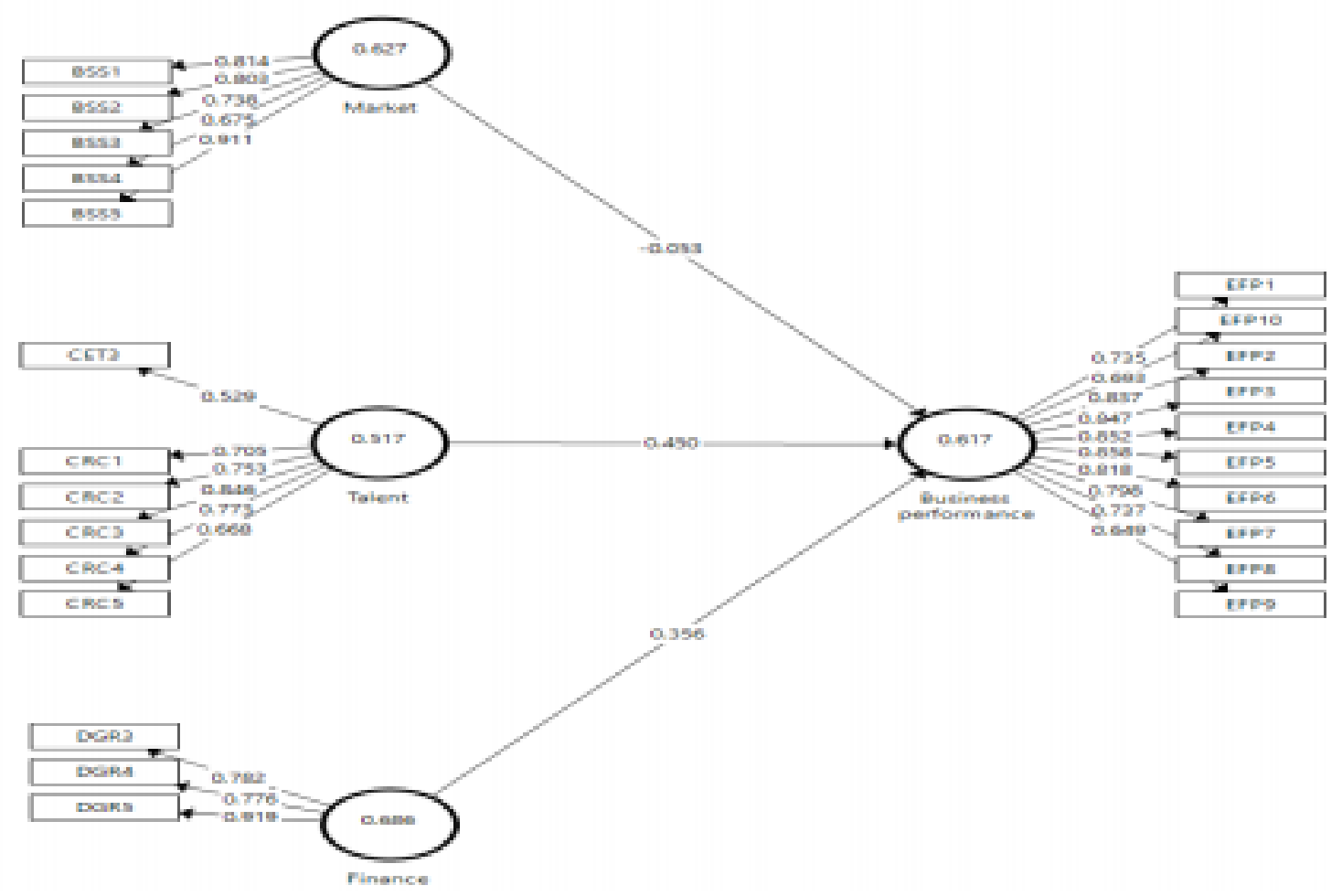

Figure 1 : Final assessment of measurement SEM-PLS framework used in the study.

Table 3: Internal consistency reliability of the variables used in the study

\begin{tabular}{|l|l|l|l|l|}
\hline & $\begin{array}{l}\text { Cronbach' } \\
\text { S Alpha }\end{array}$ & rho_A & $\begin{array}{l}\text { Composite } \\
\text { Reliability }\end{array}$ & $\begin{array}{l}\text { Average Variance } \\
\text { Extracted (AVE) }\end{array}$ \\
\hline $\begin{array}{l}\text { Business } \\
\text { performanc } \\
\text { e }\end{array}$ & 0.93 & 0.94 & $\mathbf{0 . 9 4 1}$ & 0.617 \\
\hline Finance & 0.80 & 1.09 & $\mathbf{0 . 8 6 7}$ & 0.686 \\
\hline Market & 0.86 & 0.92 & $\mathbf{0 . 8 9 3}$ & 0.627 \\
\hline Talent & 0.811 & 0.82 & $\mathbf{0 . 8 6 3}$ & 0.517 \\
\hline
\end{tabular}

Table 4 : Convergent validity of the variables used in the study

\begin{tabular}{|l|l|l|}
\hline & Number of items & AVE \\
\hline $\begin{array}{l}\text { Business } \\
\text { performance }\end{array}$ & 10 & 0.719 \\
\hline Finance & 3 & 0.599 \\
\hline Market & 5 & 0.501 \\
\hline Talent & 6 & 0.684 \\
\hline
\end{tabular}


Next, discriminant validity testifies the degree to which items differentiate among constructs or measure distinct concepts (Hair et al., 2016). The discriminant validity of the measures was examined by following the Fornell and Larcker (1981) criterion of comparing the correlations between constructs and the square root of the Average Variance Extracted (AVE) for that construct (Hair et al., 2014; Hair et al., 2011; Hair et al., 2016) (see Table 5). Items should load more strongly on their own constructs in the model, and the Average Variance Extracted (AVE) shared between each construct and its measures should be greater than the variance shared between the construct and other constructs (Hair et al., 2016). Referring to Table 2, all bolded values which represent the square root of AVE on the diagonals were greater than corresponding row and column values (correlations between constructs), thus indicating the measures were discriminant. The result demonstrated that the square roots of AVE values ranges from 0.72 to 0.83 which exceeded the off-diagonal elements in their corresponding row and column. Thus, the result indicated that the accepted threshold of Fornel-Larcker criterion is met. In sum, both convergent and discriminant validity of the measures in this study were established.

Table 5: Discriminant validity of measurement model

\begin{tabular}{|l|l|l|l|l|}
\hline & $\begin{array}{l}\text { Business } \\
\text { performanc } \\
\text { e }\end{array}$ & Finance & Market & Talent \\
\hline $\begin{array}{l}\text { Business } \\
\text { performance }\end{array}$ & $\mathbf{0 . 7 8 5}$ & & & \\
\hline Finance & 0.505 & $\mathbf{0 . 8 2 8}$ & & \\
\hline Market & 0.34 & 0.655 & $\mathbf{0 . 7 9 2}$ & \\
\hline Talent & 0.577 & 0.409 & 0.356 & $\mathbf{0 . 7 1 9}$ \\
\hline
\end{tabular}

Note: Diagonals (bolded) represent the square root of the Average Variance Extracted (AVE) while the off diagonals are correlations among constructs.

\section{Structural Model}

The assessment of the structural model involves the evaluation of path coefficient $(\beta)$, corresponding t-values and coefficient of determination $\left(R^{2}\right)$ (Hair et al., 2016). A bootstrapping procedure with 2000 resamples was applied in order to obtain the t-values. First, we looked at the predictors' business performance, which were market, talent and finance. Referring to Table 6 , only talent was found to be significant to business performance $(\beta=0.45, p<0.01)$. However, finance and market were found to be not significant to business performance. Thus, only $\mathrm{H}_{2}$ was supported. The $\mathrm{R}^{2}$ value explains 42 per cent of variance in business performance indicating a moderate model as suggested by Cohen (1988). 
Table 6 : Results of structural model analysis (Hypotheses testing)

\begin{tabular}{|l|l|l|l|l|l|l|}
\hline Measures & $\begin{array}{l}\text { Endogenous } \\
\text { constructs }\end{array}$ & $\begin{array}{l}\text { Path } \\
\text { coefficients } \\
(\boldsymbol{\beta})\end{array}$ & $\begin{array}{l}\boldsymbol{t} \\
\text { values }\end{array}$ & $\begin{array}{l}\boldsymbol{p} \\
\text { values }\end{array}$ & $\begin{array}{l}\text { Level of } \\
\text { significance }\end{array}$ & RSquare \\
\hline \multirow{2}{*}{ Finance } & \multirow{2}{*}{$\begin{array}{l}\text { Business } \\
\text { performance }\end{array}$} & 0.36 & 1.93 & 0.05 & $\mathrm{n} / \mathrm{s}$ & - \\
\cline { 4 - 7 } & \multirow{2}{*}{ Market } & -0.05 & 0.29 & 0.77 & $\mathrm{n} / \mathrm{s}$ & - \\
\cline { 3 - 7 } & & 0.45 & 3.96 & 0.00 & $\mathrm{p}<0.01$ & 0.42 \\
\hline
\end{tabular}

The study aims are to: (1) identify the components of entrepreneurial ecosystem of handicraft micro and small industries in Malaysia; (2) determine the relationship between components of entrepreneurial ecosystem and business performance. 50 survey questionnaires were distributed to handicraft entrepreneurs. Based on the results, only talent was found to have a significant positive relationship with business performance. Talent in this study is referred to highly skilled individuals with entrepreneurial mindset to be involved in entrepreneurship activity. Having relevant industrial experience and education enables entrepreneurs to achieve venture success by increasing their capabilities to explore and exploit entrepreneurial opportunities (Zainol et. al., 2018). In fact, previous studies of human capital development have proven that competent entrepreneurs are able to bring a positive impact on business performance (Zainol et. al., 2018). The fact that the nature of the handicraft industry itself that highly dependent on talent contributes to the findings as well. Since handicraft industry involves traditional and highly skilled and experience craftsmen, it is imperative to have talent as the major component of ecosystem. Thus, this findings supported the notion proposed by (e.g Isenberg, 2014; Stam, 2015; Spigel, 2017). However, the results of this study did not support market and finance as entrepreneurial components of ecosystem that lead to improved business performance. This may be due to the fact that most handicraft microentrepreneurs in Malaysia run family business that has strong establishments in terms of market and finance (Redzuan \& Aref, 2011). In fact, most of the business have the entrepreneurs as the craftsmen. Thus, this components that not influence the success of the business, not in the handicraft industry case - which is contrary to what has been proposed by (Isenberg, 2014; Stam, 2015; Spigel, 2017).

This study is also subject to certain limitations which should be taken into consideration. Firstly, all data were collected using self-reported questionnaires, increasing the likelihood of bias responses that would prevent them from providing honest responses. However, selfreported measures do provide a number of advantages that include being able to answer in private and protect sensitive information. Second, the sample size of this study was small (n $=50$ ) which made it impossible to generalize the findings of handicraft micro and small entrepreneurs in Malaysia. Future research, therefore, needs to involve a larger sample size of the respondents. Despite the limitations, the findings of this study have some useful practical implications in understanding the handicraft entrepreneurial ecosystem among micro and small entrepreneurs in Malaysia. In fact, the most important component that need to be emphasized in understanding the context of the handicraft entrepreneurial ecosystem is the role of its human capital. As talent is deemed as an important attribute in ensuring the success of business, the government and related agencies need to strengthen their role and assistance in providing these craftsmen and business owners with skills and knowledge on the 
products and the business as a whole.

\section{Conclusion}

The role of the handicraft industry in providing traditional and cultural elements to the community and nation as a whole, is not imperative. However, what is more important is providing employment opportunities for craftsmen and villages as means for them to earn their living. Despite the importance of handicraft industries, little is known about components consisted in the handicraft industry entrepreneurial ecosystem that contributes to the success of the firm. The findings of the study indicate that talent is the only component that matters in the context of micro and small handicraft industry in Malaysia. Thus, more effort needs to be put by the government and related agencies in ensuring that the industry is sustained and successful.

\section{Acknowledgements}

The authors would like to extend their appreciation to the Universiti Teknologi MARA (UITM) for the research grant entitled (Modelling Cottage Entrepreneurial Eco-system) Bridging the Gap between Malaysia and Indonesia [Grant No 600-IRMI 5/3 LESTARI (067/2019)] that made this study possible. Additionally, we would like to thank the Malaysian Handicraft Development Corporation, Ministry of Tourism, Arts and Culture Malaysia. for assistance and collaboration in collecting data for the study.

\section{References}

Alvedalen, J., \& Boschma, R. ( 2017). A critical review of entrepreneurial ecosystems research: Towards a future research agenda. European Planning Studies, 25, 887- 903.

Anderson, J. C., \& Gerbing, D. W. (1988). Structural Equation Modeling in Practice: A Review and Recommended Two-Step Approach. Psychological Bulletin, 103(3), 411-423.

Audretsch, D. B., \& Belitski, M. ( 2017). Entrepreneurial ecosystems in cities: Establishing the framework conditions. Journal of Technology Transfer, 42, 1030- 1051.

Cohen, J. (1988). Statistical power analysis for the behavioral sciences. Mahwah NJ: Lawrence Erlbaum.

Decker, R. A., Haltiwanger, J., Jarmin, R. S., \& Miranda, J. ( 2016). Where has all the skewness gone? The decline in high-growth (young) firms in the U.S. European Economic Review, $86,4-23$.

Garson, G. D. (2016). Partial Least Squares: Regression \& Structural Equation Models.

Gauthier, J. F., Penzel, M., \& Marmer, M. ( 2017). Global Startup Ecosystem Report 2017. San Francisco: Startup Genome.

Grohmann, A., \& Kauffeld, S. (2013). Evaluating Training Programs: Development and Correlates of the Questionnaire for Professional Training Evaluation. International Journal of Training and Development, 17, 135-155.

Hair, J. F., Hult, G. T. M., Ringle, C. M., \& Sarstedt, M. (2016). A primer on Partial Least Squares Structural Equation Modeling (PLS-SEM) (Second Edi). SAGE Publications, Inc.

Isenberg, D. (2014). What an entrepreneurship ecosystem actually is. Harvard Business Review Blog, May 12.

Khadhraoui, M., Lakhal, L., Plaisent, M., Bernard, P. (2016). The impact of entrepreneurial orientation on performance and customer satisfaction: The moderator effect of network capabilities. Journal of Economic Development, 8, 66-76.

Malecki (2018). EJ. Entrepreneurship and entrepreneurial ecosystems. Geography Compass, 
2, 23-50.

Maroufkhani, P., Wagner, R., \& Khairuzzaman, W. I. (2018). Entrepreneurial ecosystems: a systematic review, Journal of Enterprising Communities: People and Places in the Global Economy ,12 (4), 545-564.

Ngah, R. (2011). The relationship of intellectual capital, knowledge sharing, innovation and organizational performance of Malaysian SMEs, Unpublished Doctoral Dissertation, Universiti Malaya, Malaysia.

Rajah, S., \& Fauziah, W. Y. (2019). Malaysian Entrepreneurial Ecosystem Influence on SMEs Business Performance. Paper presented at Conference: 33rd International Business Information and Management Association IBIMA, Granada, Spain.

Redzuan, M., \& Aref, F. (2009). Barriers and opportunities in the development of rural industries: A case study of silverware and batik production in Kelantan, Peninsular Malaysia. J. Agric. \& Environ. Sci, 6 (2): 96-202.

Saad, M. N. (2014). Determinants of internalization and performance of SMEs in Malaysia, Unpublished Doctoral Thesis, Universiti Malaya, Malaysia.

Spigel, B. (2015). The Relational Organization of Entrepreneurial Ecosystems, Entrepreneurship Theory and Practice, June, 1-24.

Spigel, B. (2017). The Relational Organization of Entrepreneurial Ecosystems, Entrepreneurship Theory and Practice, 41 (1), 49-72.

Stam, E. ( 2007). Why butterflies don't leave: Locational behavior of entrepreneurial firms. Economic Geography, 83, 27- 50.

Stam, E. ( 2015). Entrepreneurial ecosystems and regional policy: A sympathetic critique. European Planning Studies, 23, 1759- 1769.

Surin, E. F. (2014). Moderating role of human capital on the relationship between social network and business performance of established manufacturing SMEs, Unpublished Doctoral Dissertation, Universiti Teknologi MARA, Malaysia.

Yan, Y., \& Guan, J. (2019). Entrepreneurial ecosystem, entrepreneurial rate and innovation: The moderating role of internet attention, Int Entrep Manag J (15), 625-650

Yojana, B., \& Sansad, M. (2006). Status Study of Tribal Handicraft- An Option for Livelihood of Tribal Community in the States of Arunachal Pradesh Rajasthan, Uttaranchal and Chhattisgarh.

Zainol, N. R., Al Mamun, A., Ahmad, G., \& Simpong, D. B. (2018). Human Capital and Entrepreneurial Competencies towards Performance of Informal Microenterprises in Kelantan, Malaysia. Economics and Sociology, 11(4), 31-50. 